\title{
Selection, assessment of virulence to Alphitobius diaperinus, and Pr1 enzyme production of Beauveria bassiana (Bals.) Vuill. isolates cultured at stress temperatures
}

\author{
Seleção, avaliação da virulência a Alphitobius diaperinus e produção \\ da enzima Pr1 de isolados de Beauveria bassiana (Bals.) Vuill. \\ submetidos a temperaturas de estresse
}

\author{
Kelly Christiane Constanski ${ }^{1 *}$; Janaina Zorzetti ${ }^{1}$; Pedro Manuel Oliveira Janeiro Neves ${ }^{2}$
}

\begin{abstract}
The entomopathogenic fungus Beauveria bassiana is a promising agent for use in insect control. Its pathogenic activity, as well as other factors such as temperature that can interfere with its development, should be assessed, thus, establishing the foundations for $B$. bassiana use in biological control programs. The objective of this study was to select and induce tolerance of $B$. bassiana isolates to high and low temperatures and to assess their virulence before and after exposure to those temperatures. A pre-selection test was performed, in which the tolerance of isolates to stress temperatures was tested and compared to the ideal growth temperature of $25^{\circ} \mathrm{C}$ for this organism. For the isolates/temperature combinations resulting in growth, conidia germination and colony-forming units (CFUs) were assessed. The isolates Unioeste 4 and Unioeste 40 exhibited $>95 \%$ germinated conidia at 16 and $31{ }^{\circ} \mathrm{C}$. Thereafter, they underwent four consecutive passages at maximum and minimum tolerated temperatures $\left(10\right.$ and $\left.37^{\circ} \mathrm{C}\right)$. A significant difference in germination was observed between the two isolates at all temperatures tested. More CFUs were observed for Unioeste 4 compared to Unioeste 40 at all temperatures, and in the case of the latter, there was no difference in CFU formation at 10 and $25^{\circ} \mathrm{C}$. For both isolates, decreased vegetative growth was observed at $37{ }^{\circ} \mathrm{C}$. Recovery of virulence was observed in both isolates, as determined by insect mortality. No relationship was observed between production of the enzyme Pr1 and the virulence of the isolates.
\end{abstract}

Key words: Entomopathogenic fungus, lesser mealworm, aviary, protease

\section{Resumo}

O fungo entomopatogênico Beauveria bassiana é relatado como um promissor agente de controle de insetos. É necessário investigar a atividade patogênica e também fatores como a temperatura que pode interferir no seu desenvolvimento, estabelecendo assim bases para o seu uso em programas de controle biológico. O objetivo desse trabalho foi selecionar e induzir a tolerância a temperaturas baixas e elevadas de $B$. bassiana e verificar a virulência desses antes e após a exposição às temperaturas. Realizou-se uma pré-seleção, onde foi verificada a tolerância dos isolados as temperaturas de estresse, os testes foram comparados à temperatura de $25^{\circ} \mathrm{C}$ ideal para o crescimento desse microrganismo. Para os isolados/temperaturas onde houve crescimento, foi avaliada a germinação de conídios e unidades formadoras de colônias. Os isolados Unioeste 4 e Unioeste 40 apresentaram mais de 95\% de conídios germinados nas temperaturas de $16{ }^{\circ} \mathrm{C}$ e $31{ }^{\circ} \mathrm{C}$. Em seguida para esses mesmos isolados foram feitas

1 PhD em Agronomia, Dept ${ }^{\circ}$ de Agronomia, Universidade Estadual de Londrina, UEL, Londrina, PR, Brasil. E-mail: kellyconstanski@gmail.com; jzorzetti@hotmail.com

2 Prof. Dr., Dept ${ }^{\circ}$ de Agronomia, UEL, Londrina, PR, Brasil. E-mail: pedroneves@uel.br

* Author for correspondence 
quatro repicagens consecutivas nas temperaturas máxima e mínima tolerada $\left(10^{\circ} \mathrm{C}\right.$ e $\left.37^{\circ} \mathrm{C}\right)$. Para a germinação foi observada diferença significativa entre os dois isolados em todas as temperaturas. Foi observada a maior formação de UFC para o isolado Unioeste 4 quando comparado com o Unioeste 40 em todas as temperaturas. Para esse mesmo isolado não houve diferença entre as temperaturas de $10^{\circ} \mathrm{C}$ e $25{ }^{\circ} \mathrm{C}$. Para ambos os isolados o menor crescimento vegetativo foi constatado a $37^{\circ} \mathrm{C}$. Foi possível verificar uma recuperação na virulência dos dois isolados na mortalidade dos insetos. Não foi observada relação na produção da enzima $\operatorname{Pr} 1$ com a virulência dos isolados.

Palavras-chave: Fungo entomopatogênico, cascudinho, aviário, protease

\section{Introduction}

Because of the selection of resistant insects, as well as the resurgence of pests and problems associated with environmental and human contamination, new studies have investigated alternative strategies to control these organisms. One major strategy is biological control through the use of natural enemies such as predators, parasitoids, or entomopathogens (SANTORO et al., 2005).

The species Beauveria bassiana is an important entomopathogen and is pathogenic to more than 200 species of insects and mites, in addition to being easily produced in vitro (ALVES, 1998). However, the use of specific organisms for microbial control requires that basic study of their isolation, biological characterization, and behavior in populations of pests and beneficial insects, and on the environment is carried out. The adoption of this type of control will require, among other important aspects, predictable performance under extreme conditions, such as temperature (LACEY et al., 2001).

Temperature is a highly important abiotic factor in the development of B. bassiana, because it governs the physiology of the fungus, and consequently its virulence, the ability to infect and kill the host. The effective use of these entomopathogens within a pest management strategy requires, among other factors, the selection of organisms that are tolerant to the temperature of the ecosystems involved (FERNANDES et al., 2008).

Therefore, the aim of this study was to select $B$. bassiana isolates that have high tolerance to stressinducing temperatures and to test if it is possible to induce tolerance by assessing germination, colony- forming units (CFUs), vegetative growth, and virulence, both before and after exposure to stress temperatures.

\section{Materials and Methods}

\section{Pre-selection of isolates}

Seven $B$. bassiana isolates (UEL 24, UEL 105, UEL 107, UNIOESTE 4, UNIOESTE 40, IBCB 87, and IBCB 98), kept in the Entomopathogen Bank of the Laboratory of Microbial Control in Insects of the Londrina State University, were used in this study.

The first phase of the study involved seeding the isolates in sporulation media (MPE) (ALVES; LECUONA, 1998) and maintaining them at $25{ }^{\circ} \mathrm{C}$ for 7 days. Following conidia production at $25{ }^{\circ} \mathrm{C}$, passaging was performed with the storage temperature ranging by $\pm 3{ }^{\circ} \mathrm{C}$. Passaging was continued until a temperature was reached at which there was no further fungal growth.

The UEL 24, UEL 105, UEL 107, IBCB 87, and IBCB 98 isolates did not grow at temperatures below $16{ }^{\circ} \mathrm{C}$ or above $31^{\circ} \mathrm{C}$; therefore, the first tests were carried out under these conditions to evaluate the germination of conidia and CFUs.

To assess germination, Petri dishes containing 20 $\mathrm{mL}$ of MPE were inoculated with $0.1 \mathrm{~mL}$ of fungal suspension standardized at $1 \times 10^{7}$ conidia $/ \mathrm{mL}$ in aqueous solution containing $0.02 \%$ Tween $20(\mathrm{v} / \mathrm{v})$. The assessment was performed $24 \mathrm{~h}$ after inoculation using an optical microscope and approximately 200 conidia were observed and divided into two fields; germinated and non-germinated conidia were quantified. 
To determine the CFU, a suspension containing $1 \times 10^{3}$ conidia $/ \mathrm{mL}$ was prepared in an aqueous solution containing $0.02 \%$ Tween $20(\mathrm{v} / \mathrm{v})$, and 0.1 $\mathrm{mL}$ of suspension was inoculated on Petri dishes containing MPE. The assessment was performed 5 days after the inoculation, by quantifying the colonies formed.

\section{Generation of tolerant isolates}

Isolates that tolerated temperatures below $16{ }^{\circ} \mathrm{C}$ and above $31{ }^{\circ} \mathrm{C}$ were seeded until a temperature that limited growth was reached. Next, successive subcultures were performed at 7-day intervals. On day 28, conidia were collected and germinated, and the CFU of each isolate was assessed as described.

Vegetative growth (VG) and conidia production were also assessed using 9-cm Petri dishes containing $20 \mathrm{~mL}$ of MPE. For this test, the fungus was inoculated onto three equally spaced points with the aid of a sterile platinum loop. On day 8 after inoculation, the area of each colony was calculated by obtaining the mean from the largest and smallest diameters, having chosen at random one colony per plate. The productivity of conidia was also assessed by cutting the center of the colonies with a circular punch $\left(2.27 \mathrm{~cm}^{2}\right)$. Discs of media containing the fungus were suspended in an aqueous solution with $0.02 \%$ Tween $20(\mathrm{v} / \mathrm{v})$ and stirred for $30 \mathrm{~s}$ in a vortex. After the necessary dilutions, the number of conidia was quantified in a Neubauer chamber.

Assessment of Unioeste 4 and Unioeste 40 virulence at all temperatures where growth occurred

To test the virulence of the two selected isolates, 50 adult insects of Alphitobius diaperinus spp. (Coleoptera: Tenebrionidae) from a commercial breeder in the city of Londrina, Paraná, were used. The insects were conditioned in an $8.5-\mathrm{cm}$ diameter acrylic plate and sprayed (airbrush sprayer coupled to a Fanem-DiaPump compressor/aspirator) with 0.5 $\mathrm{mL}$ of a suspension containing $1 \times 10^{8}$ conidia $/ \mathrm{mL}$ in $0.1 \%$ Tween $20(\mathrm{v} / \mathrm{v})$. The control was sprayed with aqueous solution containing $0.1 \%$ Tween 20 (v/v) only. Conidia produced at all temperatures $\left(10,13,16,19,22,25,28,31,34\right.$, and $\left.37^{\circ} \mathrm{C}\right)$ were used.

The insects were fed with sterilized cornmeal and kept in an air-conditioned chamber $\left(25 \pm 1{ }^{\circ} \mathrm{C}\right.$ and a $12 \mathrm{~h}$ photoperiod). The assessment was carried out on day 10 , when the dead insects were placed in a humid chamber at $25 \pm 1^{\circ} \mathrm{C}$ for 5 days to enable the fungus to emerge.

\section{Evaluation of Unioeste 4 and Unioeste 40 virulence after successive passages at stress temperatures}

To investigate whether virulence remained the same or increased with exposure to adverse conditions, isolates were passaged four consecutive times and maintained at their respective temperatures $\left(10,25\right.$, and $\left.37^{\circ} \mathrm{C}\right)$ for 7 days in each inoculation, totaling 28 days of exposure. Thereafter, the second virulence test was performed on adults of Alphitobius diaperinus as described previously.

\section{Statistical analysis}

For all experiments, a completely randomized design was used. Assays involving tolerant isolates were in a factorial $2 \times 3$ (isolate $\times$ temperature) scheme, with five replicates (plates) per treatment. In the first assay, which evaluated virulence towards Alphitobius diaperinus, a $2 \times 10$ (isolates $\times$ temperatures) +1 (control) factorial scheme was used with eight replicates of 50 insects each. In the second assay, a factorial design of $2 \times 3$ (isolates $\times$ temperatures) +1 (control) was used with six replicates of 50 insects each. All data were subjected to analysis of variance and the means were compared using Tukey's test at the 5\% significance level. 
Determination of the activity of subtilisin-like proteases (Prl) in submerged cultures of Beauveria bassiana

To investigate the activity of subtilisin-like protease $(\operatorname{Pr} 1)$, a suspension of conidia $\left(1 \times 10^{7}\right.$ conidia $/ \mathrm{mL}$ ) that was produced by the isolates at three temperatures $\left(10,25\right.$, and $\left.37^{\circ} \mathrm{C}\right)$ was placed in $10 \mathrm{~mL}$ of liquid MPE adapted from (ALVES; LECUONA, 1998), without agar and incubated for 7 days at $25{ }^{\circ} \mathrm{C}$ under agitation at $180 \mathrm{rpm}$. After incubation, the mycelium was separated from the supernatant by centrifugation at $8000 \times g$ for $15 \mathrm{~min}$. The supernatant was kept at $-20{ }^{\circ} \mathrm{C}$ and used as an enzymatic extract.

To determine Pr1-like activity (subtilisin), a synthetic specific substrate, Suc-Ala-Ala-Pro-Phe$p$-nitroaniline (Sigma), was used. The enzymatic reactions were performed following the protocol described by Donatti et al. (2008). The protocol used for enzymatic quantification is based on hydrolysis of the substrate and the release of $p$-nitroaniline, which absorbs at a wavelength of $410 \mathrm{~nm}$. Enzymatic activity of supernatants was quantified using duplicate tubes. The results obtained, in absorbance values, were converted to concentration of nanokatal (nkat), nanomol $p$-nitroaniline $/ \mathrm{mL} / \mathrm{s}$.

\section{Results and Discussion}

\section{Pre-selection}

In the germination test conducted in the preselection assay, the UEL 24, UEL 105, UEL 107, IBCB 87, and IBCB 98 isolates did not exceed $10 \%$ of germinated conidia at temperatures of 16 and $31{ }^{\circ} \mathrm{C}$ (Figure 1). This was in contrast to isolates Unioeste 4 and Unioeste 40 , which exhibited $>60 \%$ germination. At $25{ }^{\circ} \mathrm{C}$ there was no significant difference between all isolates, with $>90 \%$ germination.

Similar results were observed by Ekesi et al. (1999) who found that there was no significant difference in the germination of conidia between isolates of $B$. bassiana and Metarhizium anisopliae (Metsch.) in the temperature range of $20-30{ }^{\circ} \mathrm{C}$; however, at $35{ }^{\circ} \mathrm{C}$, all isolates displayed low germination. Sun et al. (2003) obtained similar results and concluded that besides reducing the rate of germination, high temperatures negatively affect disease transmission among insects. Other authors have also reported that increased exposure of the fungus to lower temperatures reduces the germination of conidia, possibly to zero (FERNANDES et al., 2008).

No CFUs were observed for the UEL 24, UEL 105, UEL 107, IBCB 87, and IBCB 98 isolates at 16 and $31^{\circ} \mathrm{C}$. Only Unioeste 4 and Unioeste 40 exhibited $>95 \%$ CFUs at these temperatures, a value that did not differ between the two isolates. At $25^{\circ} \mathrm{C}$, all isolates produced $>98 \%$ colonies, and there were no statistically significant differences between isolates.

\section{Tolerant isolates}

Based on the results obtained in the previous tests, the isolates Unioeste 4 and Unioeste 40 were chosen for use in the second phase of the study because they showed greater tolerance to the temperatures tested.

The conidia of both isolates displayed different germination percentages at all temperatures (Table 1), varying from 23.1 to $83.7 \%$ for Unioeste 4 , and from 0 to $94.4 \%$ for Unioeste 40 . A significant difference was observed among the isolates at all temperatures. The observation that no germinated conidia were produced by Unioeste 40 at $37{ }^{\circ} \mathrm{C}$ may be the result of delayed germination, as colony formation was observed after 5 days. Delayed germination of $B$. bassiana conidia following exposure to adverse temperatures has also been reported. Devi et al. (2005) and Alexandre et al (2006) reported that this delay may be related to the microorganism's need to repair the damage caused by exposure to stress temperature before germination, as showed for spores of Bacillus sp. by Nicholson et al. (2000). 
Figure 1. Percentage (\%) of germination of Beauveria bassiana isolates (UEL 24, UEL 105, UEL 107, UNI 4, and UNI 40, IBCB 87, IBCB 98), used in the pre-selection test at 16, 25, and 31. Lowercase letters compare the temperatures of each isolate (Tukey's test, $\mathrm{p}<0.05) ;(\mathrm{CV}=6.36 \%)$.

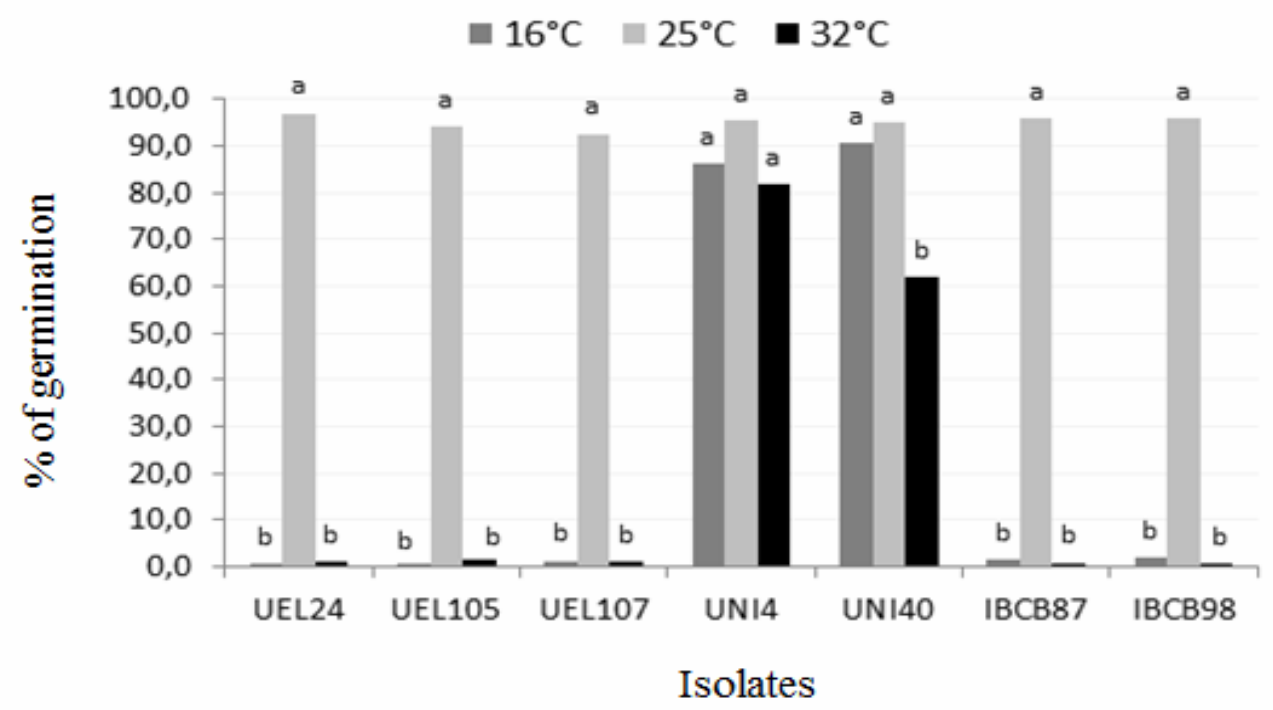

Regarding the CFUs, the isolate Unioeste 4 displayed a higher percentage of germinated conidia when compared with Unioeste 40 at all temperatures (Table 1). For this same isolate, there was no significant difference between 10 and $25{ }^{\circ} \mathrm{C}$. Some authors have noted that some species of fungi are influenced by the climate where they are found. One study showed that the distribution of Metarhizium anisopliae isolates was closely related to the abiotic conditions to which they were exposed. That is, isolates obtained from agricultural habitats were more tolerant to heat and UV than isolates collected from forest habitats and colder climates (BIDOCHKA et al., 2001). Both isolates used in the present study were from Cascavel, Paraná, Brazil (latitude -2457'21'” and longitude $\left.-53^{\circ} 27^{\prime} 19^{\prime \prime}\right)$, which is a region with a subtropical mesothermic superhumid climate, with an annual average temperature of $19{ }^{\circ} \mathrm{C}$. This partly corroborates the results obtained, which showed that lower temperatures were less harmful to both isolates.

There were no significant differences between Unioeste 4 and Unioeste 40 regarding vegetative growth (Table 1); however, the two isolates presented the lowest growth at 10 and $37{ }^{\circ} \mathrm{C}$, whereby at $37{ }^{\circ} \mathrm{C}$ both isolates produced smaller colonies than they $\mathrm{did}$ at $10{ }^{\circ} \mathrm{C}$. Thomas and Blanford (2003) also observed a deleterious effect of high temperatures on mycelium development. On the other hand, conidia production was greater for the isolate Unioeste 40 at all temperatures. This suggests that the colony area may correlate with the vegetative growth, but that it does not always reflect the true development of the fungus in terms of the amount of conidia produced (MUSTAFA; KAUR, 2009; SHAH et al., 2005). In addition, the production of conidia is highly dependent on the specific characteristics of each isolate (BUTT et al., 2001). 
Table 1. Germination percentage (\%), colony forming units (CFUs), vegetative growth, and production of conidia, of selected Beauveria bassiana isolates, after successive passages in MPE at 10, 25, and $37^{\circ} \mathrm{C}$.

\begin{tabular}{|c|c|c|c|c|c|}
\hline & \multicolumn{5}{|c|}{ Isolates } \\
\hline & \multirow{2}{*}{$\begin{array}{r}\text { Temperature } \\
10^{\circ} \mathrm{C}\end{array}$} & \multicolumn{2}{|c|}{${ }^{1}$ Unioeste 4} & \multicolumn{2}{|c|}{${ }^{1}$ Unioeste 40} \\
\hline \multirow{3}{*}{ Germination } & & $76.2 \pm 2.1$ & $\mathrm{Bb}$ & $87.3 \pm 0.9$ & $\mathrm{Ab}$ \\
\hline & $25^{\circ} \mathrm{C}$ & $83.7 \pm 1.1$ & $\mathrm{Ba}$ & $94.4 \pm 0.4$ & $\mathrm{Aa}$ \\
\hline & $37^{\circ} \mathrm{C}$ & $23.1 \pm 1.6$ & $\mathrm{Ac}$ & $0.0 \pm 0.0$ & $\mathrm{Bc}$ \\
\hline CV (\%) & \multicolumn{5}{|c|}{4.17} \\
\hline \multirow{3}{*}{ CFU } & $10^{\circ} \mathrm{C}$ & $94.2 \pm 3.0$ & $\mathrm{Aa}$ & $94.8 \pm 2.6$ & $\mathrm{Aa}$ \\
\hline & $25^{\circ} \mathrm{C}$ & $96.4 \pm 2.0$ & $\mathrm{Aa}$ & $87.8 \pm 2.9$ & $\mathrm{Bb}$ \\
\hline & $37^{\circ} \mathrm{C}$ & $41.4 \pm 2.7$ & $\mathrm{Ab}$ & $31.0 \pm 1.7$ & $\mathrm{Bc}$ \\
\hline $\mathrm{CV}(\%)$ & \multicolumn{5}{|c|}{8.85} \\
\hline \multirow{3}{*}{ Vegetative Growth } & $10^{\circ} \mathrm{C}$ & $19.1 \pm 0.6$ & $\mathrm{Ab}$ & $17.6 \pm 1.0$ & $\mathrm{Ab}$ \\
\hline & $25^{\circ} \mathrm{C}$ & $30.6 \pm 1.1$ & $\mathrm{Aa}$ & $28.2 \pm 0.6$ & Aa \\
\hline & $37^{\circ} \mathrm{C}$ & $12.7 \pm 0.8$ & $\mathrm{Bc}$ & $8.4 \pm 0.88$ & $\mathrm{Bc}$ \\
\hline $\mathrm{CV}(\%)$ & \multicolumn{5}{|c|}{9.98} \\
\hline \multirow{3}{*}{ Production of conidia $\left(10^{7}\right)$} & $10^{\circ} \mathrm{C}$ & $104.0 \pm 1.3$ & $\mathrm{Bb}$ & $123.2 \pm 4.2$ & $\mathrm{Ab}$ \\
\hline & $25^{\circ} \mathrm{C}$ & $196,0 \pm 5.2$ & $\mathrm{Ba}$ & $208.0 \pm 3.6$ & $\mathrm{Aa}$ \\
\hline & $37^{\circ} \mathrm{C}$ & $68.5 \pm 3.4$ & $\mathrm{Bc}$ & $80.2 \pm 1.3$ & Ac \\
\hline $\mathrm{CV}(\%)$ & \multicolumn{5}{|c|}{5.42} \\
\hline
\end{tabular}

${ }^{1}$ Means $( \pm$ SEM) followed by the same letter, uppercase in rows and lowercase in column, for each variable, are not significantly different by the Tukey's test $(\mathrm{p}<0.05)$.

Assessment of Unioeste 4 and Unioeste 40 virulence at all temperatures where mycelium growth occurred

Temperatures of $28-37^{\circ} \mathrm{C}$ negatively affected the virulence of $B$. bassiana conidia (Table 2), which significantly reduced insect mortality induced by the two isolates. This is in contrast to the high mortality rates observed for both isolates at 10$22{ }^{\circ} \mathrm{C}$. Other authors have described that some $B$. bassiana isolates have low tolerance towards both heat and UV-B radiation, whereas the same isolates remained active at low temperatures (FERNANDES et al., 2008). James et al. (1998) also observed that $B$. bassiana induced high rates of insect mortality at low temperatures; however, disease progression was faster at moderate temperatures. This was also reported by Santos et al. (2006), who confirmed that the mortality of $A$. diaperinus adults and larvae was significantly lower with the conidia produced at $32{ }^{\circ} \mathrm{C}$ when compared with the mortality of conidia produced $26{ }^{\circ} \mathrm{C}$. Lecuona and Alves (1988) suggested that loss of virulence, which they also observed, was caused by the negative effect of temperature on other phases of the infection process, such as host penetration or colonization.

Because of this ability to grow at low temperatures, $B$. bassiana has been recommended for use in insect control during the early spring or in climates with mild temperatures (EKESI et al., 1999). 
Table 2. Virulence of Beauveria bassiana isolates produced at different temperatures after 7 days in Alphitobius diaperinus adults.

\begin{tabular}{|c|c|c|c|}
\hline \multicolumn{4}{|c|}{ Isolates } \\
\hline & Temperature & ${ }^{1}$ Unioeste 4 & Unioeste 40 \\
\hline \multirow{10}{*}{ (\%) Total Mortality } & $10{ }^{\circ} \mathrm{C}$ & $100.0 \pm 0.0 \mathrm{Aa}$ & $79.6 \pm 2.8 \mathrm{Bb}$ \\
\hline & $13{ }^{\circ} \mathrm{C}$ & $96.6 \pm 1.4 \quad \mathrm{Aab}$ & $78.6 \pm 2.4 \mathrm{Bb}$ \\
\hline & $16{ }^{\circ} \mathrm{C}$ & $83.3 \pm 5.3 \mathrm{bc}$ & $80.3 \pm 1.4 \mathrm{Bb}$ \\
\hline & $19^{\circ} \mathrm{C}$ & $97.0 \pm 1.3 \quad \mathrm{Aab}$ & $79.6 \pm 2.3 \mathrm{Bb}$ \\
\hline & $22{ }^{\circ} \mathrm{C}$ & $99.6 \pm 0.3 \mathrm{Aa}$ & $77.6 \pm 1.6 \mathrm{Bb}$ \\
\hline & $25^{\circ} \mathrm{C}$ & $89.3 \pm 6.2$ Aabc & $95.0 \pm 2.2 \mathrm{Aa}$ \\
\hline & $28^{\circ} \mathrm{C}$ & $79.0 \pm 5.3 \mathrm{Bc}$ & $45.3 \pm 1.7 \mathrm{Ac}$ \\
\hline & $31{ }^{\circ} \mathrm{C}$ & $13.3 \pm 3.7 \mathrm{Bd}$ & $22.6 \pm 1.4 \mathrm{Ad}$ \\
\hline & $34{ }^{\circ} \mathrm{C}$ & $8.0 \pm 3.1 \mathrm{Ad}$ & $1.0 \pm 0.6 \mathrm{Ae}$ \\
\hline & $37^{\circ} \mathrm{C}$ & $5.3 \pm 0.6$ Ade & $1.0 \pm 0.4 \mathrm{Ae}$ \\
\hline & Control & & \\
\hline \multirow{10}{*}{ (\%) Confirmed Mortality } & $10{ }^{\circ} \mathrm{C}$ & $99.0 \pm 0.6 \mathrm{Aa}$ & $70.3 \pm 4.4 \mathrm{Bb}$ \\
\hline & $13{ }^{\circ} \mathrm{C}$ & $96.6 \pm 1.4$ Aab & $72.0 \pm 3.6 \mathrm{Bb}$ \\
\hline & $16^{\circ} \mathrm{C}$ & $82.3 \pm 5.4 \quad \mathrm{Abc}$ & $73.3 \pm 3.4 \mathrm{Bb}$ \\
\hline & $19^{\circ} \mathrm{C}$ & $93.6 \pm 3.7 \quad \mathrm{Aab}$ & $76.6 \pm 3.8 \mathrm{Bb}$ \\
\hline & $22{ }^{\circ} \mathrm{C}$ & $99.6 \pm 0.3 \mathrm{Aa}$ & $73.3 \pm 2.1 \mathrm{Bb}$ \\
\hline & $25^{\circ} \mathrm{C}$ & $84.6 \pm 5.4$ Aabc & $92.3 \pm 2.1 \quad \mathrm{Aa}$ \\
\hline & $28^{\circ} \mathrm{C}$ & $79.0 \pm 5.3 \mathrm{Ac}$ & $41.6 \pm 0.8 \mathrm{Bc}$ \\
\hline & $31^{\circ} \mathrm{C}$ & $6.0 \pm 3.0 \mathrm{Ad}$ & $14.0 \pm 2.07 \mathrm{Bd}$ \\
\hline & $34^{\circ} \mathrm{C}$ & $4.6 \pm 1.2 \mathrm{Ad}$ & $0.6 \pm 0.4 \mathrm{Ae}$ \\
\hline & $37^{\circ} \mathrm{C}$ & $0.0 \pm 0.0 \mathrm{Ae}$ & $0.0 \pm 0.0 \quad \mathrm{Ae}$ \\
\hline
\end{tabular}

${ }^{1}$ Means $( \pm$ SEM) followed by the same letter, uppercase in rows and lowercase in columns, for each variable are not significantly different by Tukey's test (p <0.05); CV (\%) 16.40 .

Assessment of Unioeste 4 and Unioeste 40 virulence after successive passages at stress temperatures

The conidia of Unioeste 4 and Unioeste 40 isolates produced at $25{ }^{\circ} \mathrm{C}$ caused high mortality rates. After four passages, totaling 28 days of exposure to $37^{\circ} \mathrm{C}$, there was a higher percentage of mortality when compared with the conidia produced and maintained for 7 days at the same temperature (Table 3), possibly due to the adaptation of some fungi in the micro or macroclimate, where they are cultured and/or develop.

Such exposures may lead to the selection of conidia that are more or less adapted to extreme temperatures (FARGUES et al., 1997.) This is important for pathogen survival, because microorganisms are not only exposed to adverse temperatures in the environments in which they are cultured or are established, they can also experience high temperatures due to the thermoregulation of some host insects, which raise the body temperature by habitat selection or even by laying in the sun (CHAPPELL; WHITMAN, 1990). This increase in temperature allows the infected host to recover from the disease (BLANFORD et al., 2000).

Taken together, these data support the hypothesis that different fungal characteristics, such as tolerance to temperature and virulence, can determine the success of these agents in field control. However, it is clear that more research is needed to clarify all interactions between hosts and pathogens. 
Table 3. Virulence of Beauveria bassiana isolates produced at different temperatures for 28 days, in Alphitobius diaperinus adults.

\begin{tabular}{|c|c|c|c|}
\hline & Temperature $\left({ }^{\circ} \mathrm{C}\right)$ & & \\
\hline \multirow{5}{*}{$\begin{array}{l}\text { (\%) Total } \\
\text { Mortality }\end{array}$} & & ${ }^{1}$ Unioeste 4 & Unioeste 40 \\
\hline & 10 & $86.3 \pm 0.9 \mathrm{Ab}$ & $81.0 \pm 0.8 \mathrm{Ab}$ \\
\hline & 25 & $92.3 \pm 1.8 \mathrm{Aa}$ & $97.0 \pm 0.8 \mathrm{Aa}$ \\
\hline & 37 & $44.3 \pm 1.0 \mathrm{Ac}$ & $41.3 \pm 0.7 \mathrm{Ac}$ \\
\hline & Control & & \\
\hline \multirow{4}{*}{$\begin{array}{l}\text { (\%) Confirmed } \\
\text { Mortality }\end{array}$} & 10 & $77.3 \pm 1.0 \mathrm{Ab}$ & $71.6 \pm 1.3 \mathrm{Ab}$ \\
\hline & 25 & $84.3 \pm 1.5 \mathrm{Aa}$ & $83.6 \pm 2.0 \mathrm{Aa}$ \\
\hline & 37 & $38.3 \pm 0.9 \mathrm{Ac}$ & $34.6 \pm 0.6 \mathrm{Ac}$ \\
\hline & Control & \multicolumn{2}{|c|}{$0.0 \pm 0.0 \mathrm{~d}$} \\
\hline
\end{tabular}

${ }^{1}$ Means ( \pm SEM) followed by the same letter, uppercase in rows and lowercase in columns, for each variable, are not significantly different by Tukey's test $(\mathrm{p}<0.05)$; CV $(\%): 12.55$

Determination of the Activity of Subtilisin-like Proteases (Prl) in Submerged Cultures of Beauveria bassiana

There was no significant difference in enzymatic activity $(\operatorname{Pr} 1)$ of the isolates produced at temperatures of 10,25 , and $37^{\circ} \mathrm{C}$ (Table 4 ).

Although there was some enzymatic activity, the values were low at all temperatures, which may be due to the liquid medium (MPE) used to cultivate the isolates. Culture media was observed to interfere with the production of proteases by Pinto et al. (2002). Those authors assessed the production of Pr1 and Pr2 in Metarhizium anisopliae isolates cultured in medium with and without insect cuticle, and reported that enzymes were produced in both media, but that the highest values were observed in cuticle-containing medium.

Table 4. Enzyme Activity (Pr1) of Beauveria bassiana isolates (Unioeste 4 and Unioeste 40), from cultures maintained at different temperatures after 7 days of incubation in MPE medium.

\begin{tabular}{ccccc}
\hline \multirow{3}{*}{ Temperature } & \multicolumn{4}{c}{ Isolates } \\
\cline { 2 - 5 } & Enzymatic Activity & $\mathrm{pH}$ & Enzyme Activity & $\mathrm{pH}$ \\
\cline { 2 - 5 } & $0.0013^{1}$ & 5.6 & 0.0013 & 6.4 \\
$10^{\circ} \mathrm{C}$ & 0.0013 & 7.7 & 0.0013 & 6.5 \\
$25^{\circ} \mathrm{C}$ & 0.0012 & 6.8 & 0.0008 & 5.7 \\
$37^{\circ} \mathrm{C}$ & & &
\end{tabular}

${ }^{1}$ Means are not significantly different by Tukey's test $(\mathrm{p}<0.05)$; CV $\left.=13.61 \%\right)$, Pr1 Activity expressed in nanokatol (nktol) nnomol $p$-nitroaniline $/ \mathrm{mL} / \mathrm{s}$. The results correspond to the means of three independent experiments.

To cross the main barrier of the host, the cuticle, entomopathogens use a combination of mechanical pressure and hydrolytic enzymes (proteases, cellulases, and lipases) (DUTRA et al., 2004). Other authors have claimed that these proteases are extremely important during the host infection process (CLARKSON; CHANRLEY, 1996), although, as was observed in the present study, an association between enzymatic activity and fungal virulence is not always observed, suggesting that other factors can also interfere in this process (SAFAVI et al., 2007). 


\section{Conclusions}

This study showed that temperature sensitivity varies between different $B$. bassiana isolates.

Successive passages of $B$. bassiana show increased tolerance to stress temperatures when compared to conidia not exposed to those temperatures.

Growth of $B$. bassiana isolates at 10 and 37 ${ }^{\circ} \mathrm{C}$ did not affect the Pr1 enzymatic activity of $B$. bassiana.

\section{Acknowledgments}

We thank CAPES for the doctoral scholarship granted to the first author and $\mathrm{CNPq}$ for the productivity scholarship.

\section{References}

ALEXANDRE, T. M.; ALVES, L. F. A.; NEVES, P. M. O. J.; ALVES, S. B. Efeito da temperatura e substrato sobre Beauveria bassiana e Metarhizium anisopliae e sua relação no controle do cascudinho (Alphitobius diaperinus) (Panzer) (Coleoptera: Tenebrionidae). Neotropical Entomology, Londrina, v. 35, n. 1, p. 75-82, mar. 2006.

ALVES, S. B. Fungos entomopatogênicos. In: Controle microbiano de insetos. 2. ed. Piracicaba: FEALQ, 1998. cap. 11, p. 289-381.

ALVES, S. B.; LECUONA, R. E. Epizootiologia aplicada ao controle microbiano de insetos. In: ALVES, S. B. (Ed.). Controle microbiano de insetos. Piracicaba: FEALQ, 1998. p. 97-170.

BIDOCHKA, M. J.; KAMP, A. M.; LAVENDER, T. M.; DEKONING, J.; CROOS, J. N. de. Habitat association in two genetic groups of the insectpathogenic fungus Metarhizium anisopliae: uncovering cryptic species? Applied and Environmental Microbiology, Washington, v. 67 , n. 3, p. 1335-1342, 2001.

BLANFORD, S.; THOMAS, B. M.; LANGEWALD, J. Thermal ecology of Zonocerus variegatus and its effect on biocontrol using pathogens. Agricultural and Forest Entomology, Malden, v. 8, n. 2. p. 3-10, 2000.

BUTT, T.; JACKSON, C.; MAGAN, N. Fungal biological control agents: progress, problems and potential. In: BUTT, T.; JACKSON, C.; MAGAN .N. (Ed.). Fungi as biocontrol agents: progress, problems and potential. Wallingford, United Kingdom: CABI International/ AAFC, 2001. p. 23-69.

CHAPPELL, M. A.; WHITMAN, D. W. Grasshopper thermoregulation. In: CHAPMAN, R. (Ed.). Biology of grasshoppers. New York: Wiley, 1990. p. 143-172.

CLARKSON, J. M.; CHARNLEY, A. K. New insights into the mechanisms of fungal pathogenesis in insects. Trends Microbiology, Cambridge, v. 4, n. 5, p. 197-203, 1996.

DEVI, K. U.; SRIDEVI, V.; MOHAN, C. M.; PADMAVATHI, J. Effect of high temperature and water stress on in vitro germination and growth in isolates of the entomopathogenic fungus Beauveria bassiana (Bals.) Vuillemin. Journal of Invertebrate Pathology, United Kingdom, v. 88, n. 3, p. 181-189, 2005.

DONATTI,A.C.; FURLANETO-MAIA, L.; FUNGARO, M. H. P.; FURLANETO, M. C. Production and regulation of cuticle-degrading proteases from Beauveria bassiana in the presence of Rhammatocerus schistocercoides cuticle. Current Microbiology, Heidelberg, v. 56, n. 3, p. 256-260, 2008.

DUTRA， V.; NAKAZATO.; L, BROETTO, L.; SILVEIRA, S. I.; HENNING, V. M.; SCHRANK, A. Application of representational difference analysis to identify sequence tags expressed by Metarhizium anisopliae during the infection process of the tick Boophilus microplus cuticle. Research in Microbiology, Philadelphia, v. 155, n. 2, p. 245-251, 2004.

EKESI, S.; MANIANIA, K. N.; AMPONG-NYARKO, K. Effect of temperature on germation, radial growth and virulence of Metarhizium anisopliae and Beauveria bassiana on Megalurothrips sjostedti. Biocontrol Science and Technology, United Kingdom, v. 9, n. 4, p. 177-185, 1999.

FARGUES, J.; GOETTEL, M. S.; SMITS, N.; OUEDRAOGO, A.; ROUGIER, M. Effect of temperature on vegetative growth of Beauveria bassiana isolates from different origins. Mycologia, Califórnia, v. 89, n. 2, p. 383-392, 1997.

FERNANDES, E. K. K.; RANGEL, D. E. N.; MORAES, A. M. L.; BITTENCOURT, V. R. E. P.; ROBERTS, D. W. Cold activity of Beauveria and Metarhizium, and thermotoleranc of Beauveria. Journal of Invertebrate Pathology, Bethesda, v. 98, n. 1, p. 69-78, 2008.

JAMES, R. R.; CROFT, B. A.; SHAFFER, B. T.; LIGHTHART, D. B. Impact of Temperature and Humidity on Host-Pathogen Interactions Between Beauveria bassiana and a Coccinellid. Environmental Entomology, Annapolis, v. 27, n. 6, p. 506-513, 1998. 
LACEY, L. A.; FRUTOS, R.; KAYA, H. K.; VAIL, P. Insect pathogens as biological controlagents: do they have a future? Biological Control, United Kingdom, v. 21, n. 4, p. 230-248, 2001.

LECUONA, R. E.; ALVES, S. B. Efficiency of Beauveria bassiana (Bals.) Vuill., B. brongniartii (Sacc.) Petch. And granulose virus on Diatraea saccharalis (F., 1794) at different temperatures. Journal Applied Entomology, Berlin, v. 105, n. 76, p. 223-228, 1988.

MUSTAFA, U.; KAUR, G. Effects of carbon and nitrogen sources and ratio on the germination, growth and sporulation characteristics of Metarhizium anisopliae and Beauveria bassiana isolates. African Journal of Agricultural Research, Lagos, v. 4, n. 104, p. 922-930, 2009.

NICHOLSON, W. J.; MUNAKATA, N.; HORNECK, G.; MELOSH, H. J.; SETLOW, P. Resistance of Bacillus endospores to extreme terrestial and extraterrestrial environments. Microbiology and Molecular Biology Reviews, Washington, v. 64, n. 3, p. 548-572. 2000.

PINTO, F. G. S.; FUNGARO, M. H. P.; FERREIRA, J. M.; VALADARES-INGLIS, M. C.; FURLANETO, M. C. Genetic variation in the cuticle-degrading protease activity of the entomopathogen Metarhizium flavoviride. Genetics and Molecular Biology, Ribeirão Preto, v. 25, n. 2, p. 231-234, 2002.
SAFAVI, S. A.; SHAH, F. A.; PAKDEL, A. K.; RASOULIAN, G. R.; BANDANI, A. R.; BUTT, T. M. Effect of nutrition on growth and virulence of the entomopathogenic fungus Beauveria bassiana. FEMS Microbiology Letters, Chichester, v. 270, n. 2, p. 116123, 2007.

SANTORO, P. H.; NEVES, P. M. O. J.; SILVA, R. Z.; AKIMI, S.; ZORZETTI, J. Produção de esporos de Beauveria bassiana (Bals). Vuill. num processo bifásico utilizando diferentes meios líquidos. Semina: Ciências Agrárias, Londrina, v. 26, n. 3, p. 313-320, 2005.

SANTOS, J. C. dos; ALVES, L. F. A.; BONINI, A. K.; ROHDE, C. Efeito da combinação de espécies de fungos entomopatogênicos e de temperatura de incubação na mortalidade de Alphitobius diaperinus Panzer (Coleoptera: Tenebrionidae). Semina: Ciências Agrárias, Londrina, v. 27, n. 4, p. 525-532, 2006.

SHAH, F. A.; WANG, C. S.; BUTT, T. M. Nutrition influences growth and virulence of the insectpathogenic fungus Metarhizium anisopliae. FEMS Microbiology Letters, Chichester, v. 251, n. 8, p. 259-266, 2005.

SUN, J.; FUXA, J. R.; HENDERSON, G. Effects of virulence, sporulation, and temperature on Metarhizium anisopliae and Beauveria bassiana laboratory transmission in Coptotermes formosanus. Journal of Invertebrate Pathology, United Kingdom, v. 84, n. 2, p. 38-46, 2003.

THOMAS, M. B.; BLANFORD, S. Thermal biology in insect-parasite interactions. Trends in Ecology \& Evolution, Cambridge, v. 18, n. 4, p. 344-350, 2003. 